\title{
KESIAPAN DAN STRATEGI KEBIJAKAN PENGEMBANGAN MINAPOLITAN BERBASIS PERIKANAN BUDIDAYA
}

\author{
Hikmah dan Agus Heri Purnomo \\ Balai Besar Penelitian Sosial Ekonomi Kelautan dan Perikanan \\ Jl. KS. Tubun Petamburan VI Jakarta 10260 \\ Telp. (021) 53650162, Fax. (021)53650159 \\ E-mail: hikmah_madani@yahoo.com
}

Diterima 7 Mei 2012 - Disetujui 20 Juni 2012

\begin{abstract}
ABSTRAK
Tulisan ini mengkaji strategi kebijakan dalam pengembangan kawasan minapolitan berbasis perikanan budidaya. Secara spesifik kajian ini bertujuan untuk (1) memetakan indeks kesiapan pelaksanaan minapolitan yang dilihat dari aspek-aspek generik (sosial ekonomi yang meliputi aspek masyarakat dan bisnis, aspek sumberdaya dan tata ruang, aspek kelembangaan, aspek kebijakan dan governance dan aspek Infrastruktur, aspek teknologi dan aspek pemasaran di kawasan minapolitan budidaya), (2) memetakan kekuatan, kelemahan, peluang dan ancaman dalam pelaksanaan minapolitan, serta (3) merumuskan strategi kebijakan pengembangan minapolitan berbasis perikanan budidaya. Penelitian ini menggunakan pendekatan mail survey dan survei. Metode analisis yang digunakan adalah menggunakan metode analisis deskriptif kualitatif dengan alat analisis SWOT. Hasil penelitian menunjukkan tiga kategori indeks kesiapan pelaksanaan minapolitan yaitu pemula, maju dan mandiri. Berdasarkan tiga kategori tersebut di identifikasi kekuatan, kelemahan, peluang dan ancaman pengembangan minapolitan perikanan budidaya. Rumusan strategi kebijakan pengembangan kawasan minapolitan memperhitungkan unsur-unsur kekuatan, kelemahan, kekuatan dan ancaman pada masing-masing aspek.
\end{abstract}

Kata Kunci: kesiapan strategi, kebijakan, minapolitan, perikanan budidaya

\section{Abstract: Readinees and Policy of Strategy Minapolitan Development Culture-Based Fisheries. By: Hikmah and Agus Heri Purnomo}

This paper analyzed the strategy of regional development policy in minapolitan based aquaculture. Specifically, this study aimed to (1) mapping the readiness index of implementation minapolitan which seen from the generic aspects (including socioeconomic aspects of society and business, resources and spatial aspects, institutional aspects, aspects of the policy and governance and infrastructure aspects, aspects of technology and marketing aspects of aquaculture in the region minapolitan), (2) mapping the strengths, weaknesses, opportunities and threats in minapolitan implementation, and (3) formulate policy strategies based minapolitan aquaculture development. This study using a mail survey and the survey approach. The analytical method used was qualitative descriptive analysis method with a SWOT analysis. The results showed three categories of implementation readiness index minapolitan the beginner, advanced and independent. Based on these three categories in the identification of strengths, weaknesses, opportunities and threats minapolitan aquaculture development. The formulation of development strategies minapolitan policy taking into account the elements such as strengths, weaknesses, strengths and threats at each aspects.

Keywords: strategy, policy, minapolitan, aquaculture 


\section{PENDAHULUAN}

Penetapan minapolitan oleh Kementerian Kelautan dan Perikanan (KKP) sangat relevan dengan visi misi KKP, yang memfokuskan pada peningkatan produksi dan kesejahteraan masyarakat. Minapolitan dijadikan sebagai sarana untuk mewujudkan visi tersebut. Sebagai negara penghasil produk perikanan terbesar didunia, ditetapkan perikanan budidaya sebagai ujung tombak penghasil produk perikanan. Upaya peningkatan produksi ikan diharapkan mampu memenuhi kebutuhan pangan ikan dan konsumsi ikan masyarakat meningkat. Selain itu, dengan adanya peningkatan produksi melalui program minapolitan ini peluang pasar ikan yang terbuka di pasaran regional dan global dapat dimanfaatkan oleh Indonesia. Terkait dengan hal itu, Kementerian Kelautan dan Perikanan mengangkat minapolitan sebagai isu nasional yang tujuannya untuk mengembangkan sistem dan usaha minabisnis, sehingga akan mengurangi kesenjangan kesejahteraan pendapatan antar masyarakat, mengurangi kemiskinan dan mencegah terjadinya urbanisasi tenaga produktif, serta akan meningkatkan Pendapatan Asli Daerah.

Secara konseptual, minapolitan mempunyai dua unsur utama yaitu, minapolitan sebagai konsep pembangunan sektor kelautan dan perikanan berbasis wilayah dan minapolitan sebagai kawasan ekonomi unggulan dengan komoditas utama produk kelautan dan perikanan. Secara ringkas minapolitan dapat didefinisikan sebagai konsep pembangunan ekonomi kelautan dan perikanan berbasis wilayah dengan pendekatan dan sistem manajemen kawasan berdasarkan prinsip integrasi, efisiensi dan kualitas serta akselerasi tinggi. Sementara itu, kawasan minapolitan adalah kawasan ekonomi berbasis kelautan dan perikanan yang terdiri dari sentra-sentra produksi dan perdagangan, jasa, permukiman, dan kegiatan lainnya yang saling terkait (Sunoto, 2010).

Konsep Minapolitan (kota dengan basis ekonomi sub sektor perikanan) merupakan salah satu upaya meningkatkan percepatan pembangunan perdesaan melalui pelaksanaan pembangunan pada desa-desa pusat pertumbuhan. Dalam perkembangannya kawasan minapolitan diharapkan mampu melayani, mendorong dan menarik kegiatan pembangunan agribisnis di wilayah hinterlandnya. Struktur tata ruang kawasan minapolitan terdiri dari kota tani (desa dengan fasilitas kota) sebagai pusat kegiatan agroindustri (hilir), pusat pelayanan agribisnis, serta kawasan desa pemasok bahan baku yang berupa produksi primer (KKP, 2011).

Secara faktual, permasalahan yang dihadapi dalam pengembangan minapolitan diantaranya adalah tidak semua lokasi Kabupaten/Kota memiliki tingkat kesiapan dalam pelaksanaan minapolitan sesuai dengan yang dipersyaratkan dalam pedoman pelaksanaan Minapolitan menurut Keputusan Menteri Kelautan dan Perikanan No. 18/MEN/2011. Persyaratan tersebut antara lain: memiliki potensi dan kondisi perikanan, komoditas unggulan, sudah ada kegiatan produksi perikanan di kawasan minapolitan, adanya fasilitas pendukung, sudah ada kelembagaan perikanan, kelayakan lingkungan, rencana tata ruang wilayah, rencana induk pembangunan jangka menengah, dan masterplan.

Hasil penelitian BBRSEKP (2010), permasalahan dalam pelaksanaan program minapolitan meliputi beberapa aspek generik, di antaranya: permasalahan utama adalah pada sistem koordinasi antar unit instansi baik pusat, pemerintah daerah maupun dinas-dinas terkait juga sistem mobilisasi komitmen pemerintah daerah, tata ruang yang dipersiapkan oleh daerah sering tidak mencantumkan lokasi sentra minapolis bahkan beberapa daerah belum melengkapi persyaratan dalam bentuk penyediaan Rencana Pembangunan Investasi Jangka Menengah (RPIJM) dan masterplan, kesenjangan antara sistem kelembagaan yang dipersyaratkan dan kondisi yang mampu dipersiapkan oleh sebagian besar daerah. Hal lain adalah penguasaan teknologi budidaya dan manajemen wirausaha oleh pelaku usaha, dan penyediaan harga input yang terjangkau, yang semestinya merupakan sasaran pengembangan, namun pada kenyataannya diposisikan sebagai syarat minapolitan, sehingga pada umumnya sulit terpenuhi oleh daerah 
pelaksanaa program minapolitan. Keberadaan balai benih ikan (BBI) yang terkonsentrasi hanya di lokasi-lokasi tertentu juga menyebabkan kesulitan untuk memasok kebutuhan benih ikan ke daerah-daerah pengembang minapolitan, yang lokasinya tersebar.

Tulisan ini bertujuan memetakan indeks kesiapan pelaksanaan minapolitan yang dilihat dari aspek-aspek generik (sosial ekonomi yang meliputi aspek masyarakat dan bisnis, aspek sumberdaya dan tata ruang, aspek Kelembangaan, aspek kebijakan dan governance, aspek infrastruktur, aspek teknologi dan aspek pemasaran di kawasan minapolitan budidaya), memetakan kekuatan, kelemahan, peluang dan ancaman dalam pelaksanaan minapolitan, serta merumuskan strategi kebijakan pengembangan minapolitan berbasis perikanan budidaya.

\section{METODOLOGI}

\section{Lokasi dan Waktu Penelitian}

Penetapan lokasi penelitian dilakukan secara sengaja (purposive sampling). Menurut Hasan (2000), ada dua jenis sampel dalam teknik purposive sampling yaitu judgment sampling dan qouta sampling. Dalam penelitian ini, penetapan lokasi didasarkan pada lokasi yang tercantum dalam SK Menteri Kelautan dan perikanan No. 32 tahun 2010 tentang penetapan kawasan minapoltan. Diantara mereka yang mengembalikan kuesioner mail survey sebanyak 98 kabupaten/ kota. Untuk verfikasi data mail survey dilakukan di 9 (sembilan) lokasi penelitian yaitu Kabupaten Bogor, Banjar, Sleman, Pangkep, Lamongan, Bintan,
Waingapu, Kota Jayapura. Kabupaten dan kota tersebut dianggap mewakili komoditas unggulan dan mewakili tipologi wilayah Indonesia Barat, Tengah dan Timur.

\section{Pendekatan dan Metoda Analisis}

Penelitian ini dilakukan menggunakan metode deskriptif. Maman (2002), mengungkapkan bahwa penelitian deskriptif berusaha menggambarkan gejala sosial. Pendekatan yang digunakan cross-section dan studi kasus. Menurut Vredenbregt (1987) studi kasus ialah suatu pendekatan yang bertujuan untuk mempertahankan keutuhan (wholeness) dari obyek, artinya data yang dikumpulkan dalam rangka studi kasus dipelajari sebagai suatu keseluruhan yang terintegrasi. Penelitian studi kasus bersifat sebagai penelitian yang eksploratif dan deskriptif.

Pengumpulan data dilakukan dengan menggunakan kuesioner terstruktur, kemudian dikirim via email dan pos ke 135 lokasi kota/ kabupaten. Untuk verifikasi data di sembilan lokasi kabupaten/kota, pengumpulan data dilakukan melalui observasi dan wawancara in depht interview. Data yang terkumpul dilakukan tabulasi, dikonstruksi berdasarkan pada tujuh aspek minapolitan. Indeks kesiapan dihitung dari nilai skor seluruh pertanyaan ke tujuh aspek minapolitan dibagi total skor keseluruhan dikali 100 persen dalam kuesioner mail survey dengan kisaran 0-5. Masing-masing aspek tersebut terdiri dari jumlah pertanyaan yang berbeda dan besar nya nilai juga berbeda dari masingmasing lokasi, sebagai berikut:

Tabel 1. Jumlah Pertanyaan dalam Kuesioner Aspek Minapolitan Tahun 2011.

Table 1. Amount of Questions Aspects Minapolitan in Questionnaire, 2011.

\begin{tabular}{llc}
\hline No. & \multicolumn{1}{c}{ Aspek Minapolitan/ Aspects Minapolitan } & Jumlah Pertanyaan/ Amount of Questions \\
\hline 1. & Infrastruktur/ infrastructure & 56 \\
2. & Masyarakat dan Bisnis/Community and Business & 11 \\
3. & Sumberdaya dan Tata Ruang/ Resources and Spatial & 5 \\
4. & Kelembagaan/ Institutional & 15 \\
5. & Teknologi/ Technology & 12 \\
6. & Kebijakan dan Governance/ Policy and & 26 \\
& Governance & \\
7. & Pemasaran/ Marketing & 7 \\
\hline
\end{tabular}


Berdasarkan perhitungan skor diatas, ditentukan kriteria indeks kesiapan pelaksanaan minapolitan didasarkan justifikasi sebagai berikut:

\begin{tabular}{|c|c|}
\hline $\begin{array}{l}\text { Perintis } \\
(0-<50)\end{array}$ & $\begin{array}{l}\text { Jika unsur-unsur as- } \\
\text { pek-aspek generik ada } \\
\text { namun belum mema- } \\
\text { dai }\end{array}$ \\
\hline $\begin{array}{l}\text { Pemula } \\
(>50-<75)\end{array}$ & $\begin{array}{l}\text { Jika unsur - unsur } \\
\text { aspek-aspek generik } \\
\text { mulai berkembang }\end{array}$ \\
\hline Maju $(75-<85)$ & $\begin{array}{l}\text { Jika aspek-aspek gen- } \\
\text { erik sudah berkembang } \\
\text { dan berfungsi namun } \\
\text { tidak terintergrasi }\end{array}$ \\
\hline Mandiri (>85) & $\begin{array}{l}\text { Jika aspek-aspek gen- } \\
\text { erik ada, berfungsi dan } \\
\text { terintegrasi antar aspek }\end{array}$ \\
\hline
\end{tabular}

Selanjutnya dilakukan analisis data dengan menggunakan analisis deskriptif kualitatif. Penentuan strategi kebijakan pengembangan minapolitan di identifikasi dari lingkungan strategis internal dan eksternal pengembangan minapolitan berbasis budidaya. Perumusan strategi kebijakan menggunakan analisis SWOT, yaitu menganalisis kekuatan (Strength), kelemahan (Weakness), peluang (Opportunity) dan ancaman (Threat) dari pengembangan kawasan minapolitan. Analisis SWOT (Rangkuti, 2005) merupakan jenis analisis yang digunakan untuk memaksimalkan kekuatan dan peluang, namun pada saat bersamaan dapat meminimumkan kelemahan dan ancaman.

\section{PETA INDEKS KESIAPAN MINAPOLITAN}

Berdasarkan hasil skor mail survey, indeks kesiapan pelaksanaan minapolitan yang tergolong kategori pemula terdapat 2 lokasi yaitu Kabupaten Banyuasin dengan indeks kesiapan 48,47 \% dan Kabupaten Kalabahi dengan nilai indeks $37,88 \%$. Indeks kesiapan pelaksanaan minapolitan kategori maju terdapat 80 kabupaten/kota dengan nilai indeks terendah adalah Kabupaten Perigi Moutong dengan nilai indeks 50,97 dan indeks tertinggi adalah Kabupaten Tuban dengan nilai indeks $74,37 \%$. Indeks kesiapan pelaksanaan minapolitan kategori mandiri terdapat 7 (tujuh) lokasi kabupaten/kota dengan nilai indeks terendah adalah Kabupaten Brebes dengan indeks kesiapan 75,21 \% dan indeks kesiapan tertinggi adalah Kabupaten Agam dengan indeks kesiapan 83,57. Gambar 1 dan Lampiran 1 menunjukkan indeks kesiapan pelaksanaan minapolitan berbasis perikanan

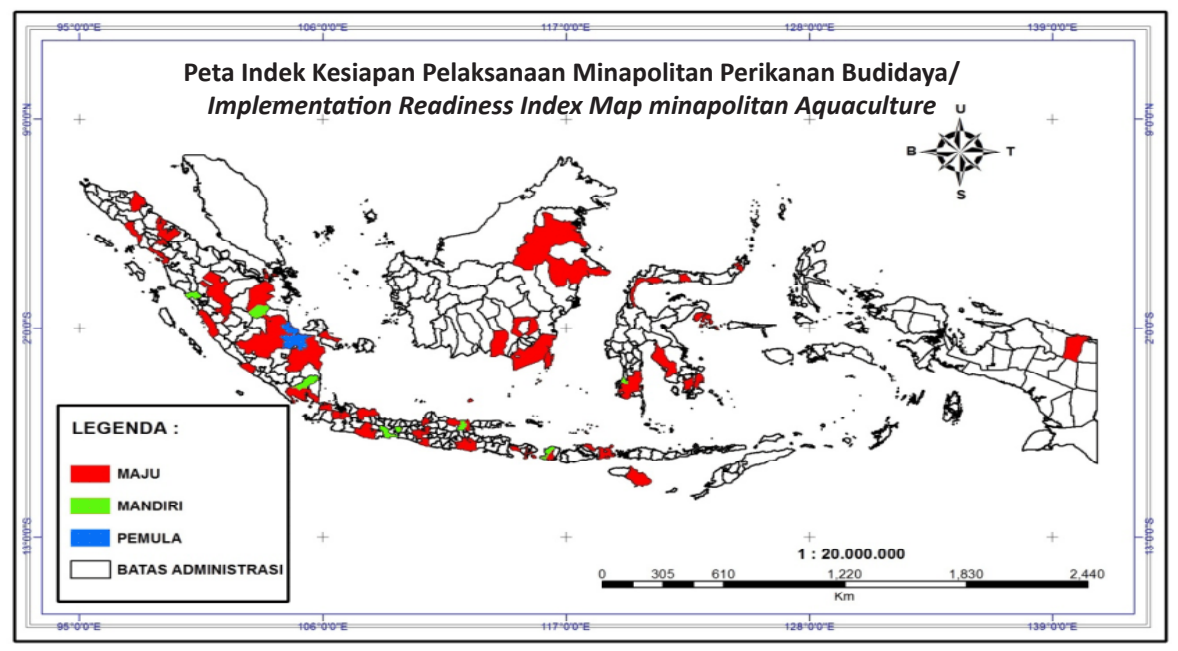

Gambar 1. Peta Indeks Kesiapan Pelaksanaan Minapolitan Budidaya, 2011. Figure 1. Implementation Readiness Index Map Minapolitan Cultivation, 2011. 
budidaya di seluruh lokasi mail survey.

Jika dilihat dari persentasi skor indeks kesiapan pelaksanaan minapolitan, daerahdaerah yang termasuk kategori pemula masih memiliki berbagai kelemahan di berbagai aspek antara lain aspek infrastruktur, sumberdaya dan tata ruang, kelembagaan, teknologi, kebijakan dan governance. Dari persentasi skor pada Gambar 2 menunjukkan beberapa aspek masih dibawah $60 \%$. Aspek yang paling rendah adalah aspek teknologi dan aspek infrastruktur dengan skor 28,76 dan 30,77\%. Dalam hal ini, untuk kategori pemula masih belum memenuhi persyaratan pengembangan minapolitan. Berdasarkan SK Menteri Kelautan dan Perikanan No. 18 tahun 2011, salah satu persyaratan pengembangan kawasan minapolitan antara lain adalah ketersediaan infrastruktur sarana dan prasarana pendukung perikanan, teknologi dan adanya komitmen daerah dalam bentuk kebijakan.

Gambar 3 menunjukkan persentase skor indeks kesiapan pelaksanaan minapolitan pada kategori maju terlihat persentasi skor dibawah $60 \%$ yaitu pada aspek infrastruktur. Sementara aspek yang memiliki persentase skor diatas $70 \%$ nilainya adalah aspek kebijakan dan governance $(71,20 \%)$ dan aspek pemasaran hasil budidaya $(82,53 \%)$. Hal ini menggambarkan bahwa pada kategori ini dari sisi infrastruktur sudah mulai berkembang namun masih minim. Sementara aspek lainnya seperti aspek masyarakat dan bisnis, sumberdaya dan tata ruang, kelembagaan, kebijakan dan tata kelola pemerintahan, dan pemasaran hasil perikanan sudah cukup berkembang.

Gambar 4 memperlihatkan persentasi indeks kesiapan kategori mandiri dimana ratarata persentasi nilai skornya secara keseluruhan diatas $70 \%$. Rata-rata nilai persentse skor infrastruktur (74,21\%), masyarakat dan bisnis $(78,19 \%)$, sumberdaya dan tata ruang $(77,38 \%)$, kelembagaan $(84,87 \%)$, teknologi $(86,54 \%)$, kebijakan dan governance $(78,20 \%)$ dan pemasaran hasil budidaya (88,98\%). Hal menggambarkan kondisi existing pada masing-masing sudah berkembang dengan baik.

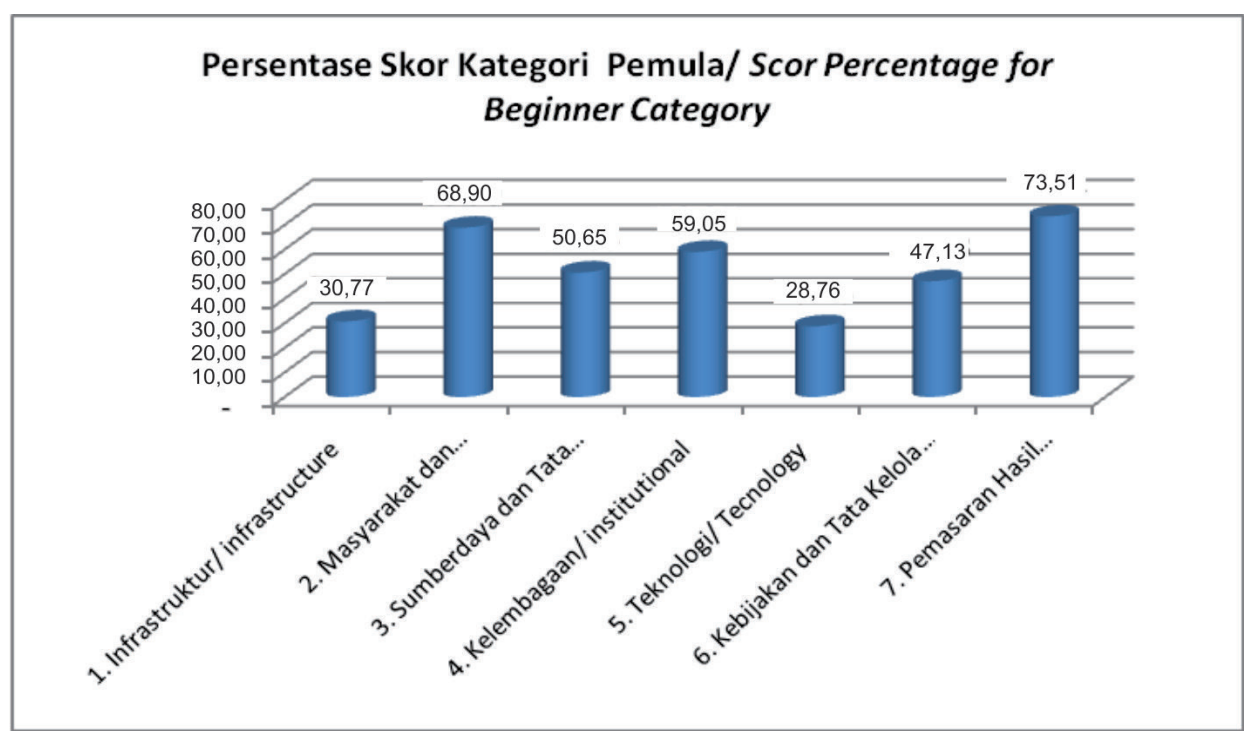

Gambar 2. Persentasi Skor Pada Masing-masing Aspek Minapolitan Budidaya Kategori Pemula di Lokasi Mail Survey, 2011.

Figure 2. Percentage Score in Each Category Beginner Minapolitan Cultivation Aspects in Mail Survey Location, 2011. 


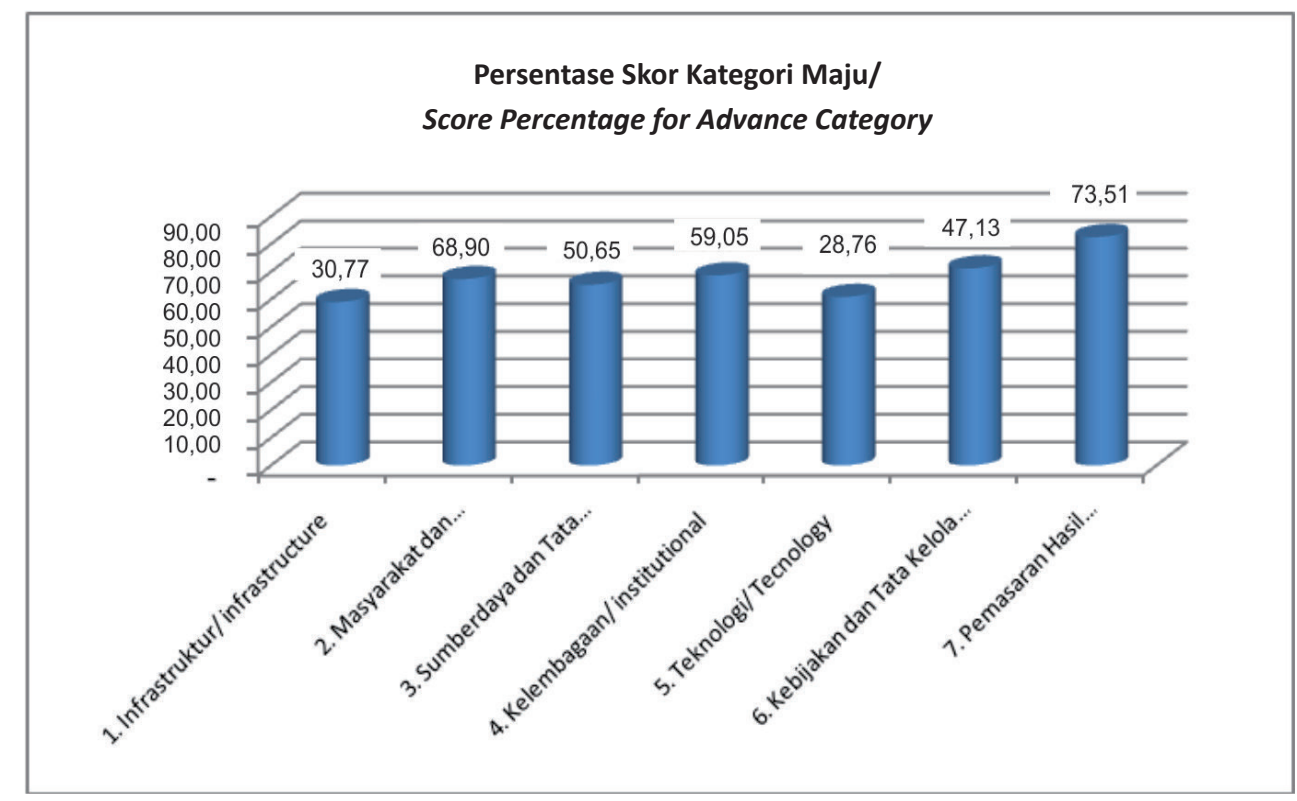

Gambar 3. Persentasi Skor pada Masing-masing Aspek Minapolitan Budidaya Kategori Maju di Lokasi Mail Survey, 2011.

Figure 3. Percentage Score in Each Category Advance Minapolitan Cultivation Aspects in Mail Survey Location, 2011.

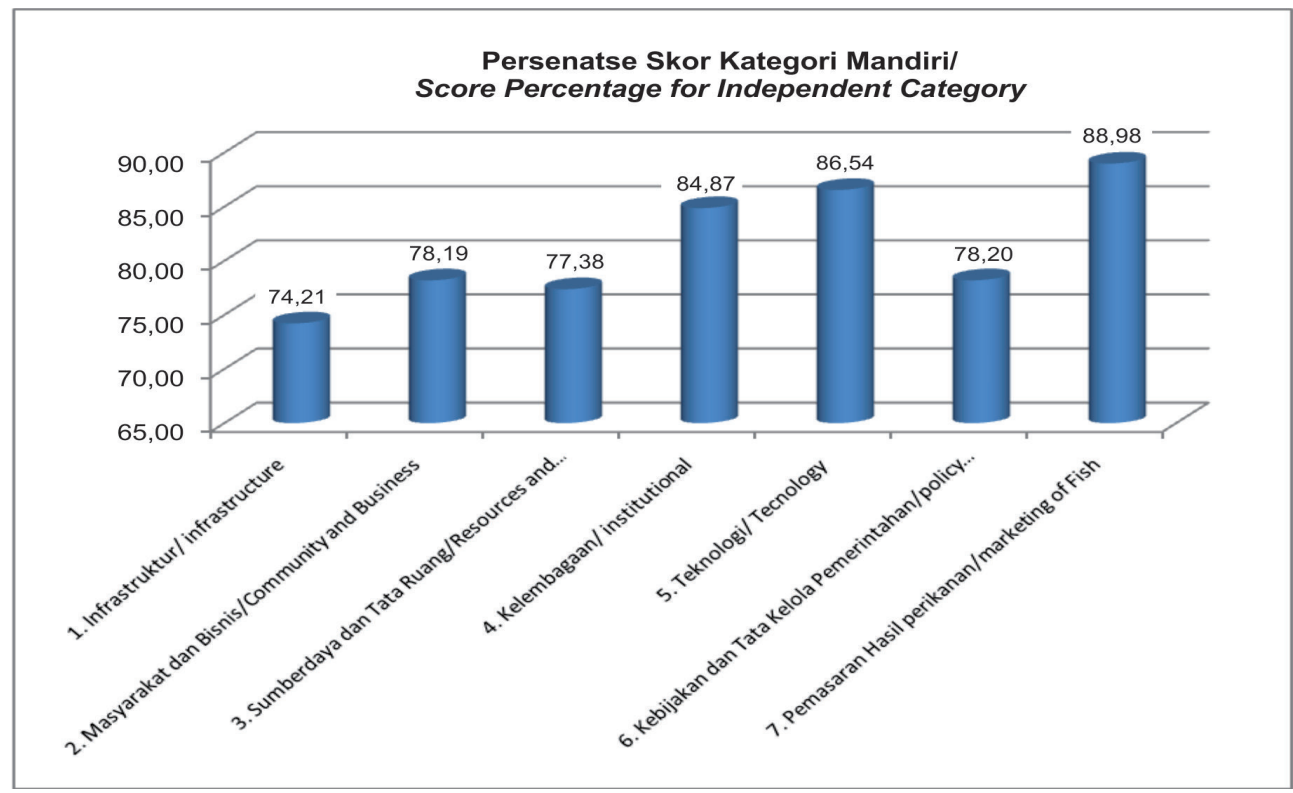

Gambar 4. Persentasi Skor Pada Masing-masing Aspek Minapolitan Budidaya Kategori Mandiri di Lokasi Mail Survey, 2011.

Figure 4. Percentage Score in Each Category Independent Aspect Minapolitan Cultivation in Mail Survey Location, 2011. 
Jika dilihat dari ketiga kategori kesiapan pelaksanaan minapolitan tersebut di atas, kategori yang mendapat prioritas utama dalam pengembangan kawasan minapolitan adalah kategori mandiri dengan persentasi kesiapan pelaksanaan minapolitan diatas 70 persen.

\section{INDENTIFIKASI ASPEK STRATEGIS INTERNAL DAN EKSTERNAL}

Identifikasi aspek strategis internal dan eksternal masing-masing kategori kesiapan pelaksanaan pengembangan kawasan minapolitan yaitu pemula, maju dan mandiri yang meliputi aspek-aspek kelembagaan, sumber daya dan tata ruang, sistem minabisnis untuk menentukan strategi kebijakan apa yang diperlukan pada setiap kategori pelaksanaan minapolitan berbasis budidaya (Tabel 2).

Kategori pemula, unsur-unsur penciri yang menjadi kekuatan, kelemahan, peluang dan ancaman sebagai berikut:

Kekuatan, unsur-unsur yang menjadi kekuatan dalam pengembangan minapolitan berbasis budidaya antara lain potensi lahan sangat mendukung kegiatan budidaya perikanan, berfungsinya kelompok pembudidaya, dan sebagian besar masyarakat setempat melakukan usaha budidaya.

Kelemahan, unsur-unsur yang menjadi kelemahan dalam pengembangan minapolitan kategori pemula terutama pada aspek infrastruktur yang masih belum memadai terutama dalam hal sarana dan prasarana input produksi, kecukupan dan kualitas air untuk budidaya, kurang berfungsinya saluran irigasi. Pada aspek kelembagaan, terutama unsurunsur yang menjadi kelemahan pengembangan minapolitan antara lain akses tehadap permodalan dan kelembagaan penyuluhan yang kurang berperan aktif dalam pengembangan iptek bagi masyarakat pembudidaya.

Peluang, unsur-unsur yang menjadi peluang dalam pengembangan minapolitan antara lain komitmen pemerintah daerah dalam pengembangan kawasan minapolitan, sudah ada tata ruang kab/kota, jangkauan pemasaran sudah mencapai di luar Kabupaten, tingkat konsumsi ikan makin tinggi.

Ancaman, unsur-unsur yang menjadi ancaman dalam pengembangan kawasan minapolitan berbasis budidaya pada kategori pemula antara lain belum adanya masterplan, terbatasnya sarana infrastruktur yang menunjang kegiatan bdidaya seperti sarana transportasi, jaringan komunikasi dan listrik.

Kategori maju, unsur-unsur yang menjadi kekuatan, kelemahan, peluang dan ancaman sebagai berikut:

Kekuatan, memiliki potensi sumber daya perikanan yang sangat potensial, sebagian besar masyarakat setempat melakukan usaha budidaya, tersedianya sarana Balai Benih Ikan (BBI) dan Unit Pembenihan Rakyat (UPR), tersedianya sarana input produksi untuk budidaya, pasokan listrik, BBM dan saluran komunikasi sudah memadai, kondisi infrastruktur jalan produksi baik dan memadai, tersedianya saluran irigasi, sudah ada tata ruang untuk pengelolaan perikanan budidaya, berkembangnya kelembagaan kelompok pembudidaya.

Kelemahan, rendah tingkat pengetahuan pembudidaya tentang teknologi budidaya, harga input pakan tinggi, rendahnya akses terhadap permodalan usaha, belum ada sertifikasi benih, lemahnya daya saing produk.

Peluang, komitmen pemerintah daerah dalam pengembangan kawasan minapolitan, sudah ada Rencana Tata Ruang Wilayah (RTRW), tingkat konsumsi ikan yang semakin tinggi.

Ancaman, unsur-unsur yang menjadi ancaman pengembangan minapolitan kategori maju antara lain masuknya ikan impor dan harga ikan yang rendah ketika produksi meningkat.

Hasil identifikasi menggambarkan kekuatan dan peluang untuk pengembangan kawasan minapolitan perikanan budidaya lebih besar, baik dari aspek potensi sumber daya perikanan, sumber daya manusia, infrastruktur, 
kelembagaan terutama kelembagaan kelompok yang sudah berfungsi. Kemudian dari sisi dukungan kebijakan dan governance sudah ada dalam bentuk komitmen pemda dalam pelaksanaan minapolitan serta sudah adanya tata ruang untuk pengembangan minapolitan perikanan budidaya. Sementara kelemahan-kelemahan serta ancaman masih ada terutama pada kebijakan dan governance mengenai harga pakan yang terlalu tinggi dan adanya impor ikan dari luar.

Tabel 2. Identifikasi SWOT Pada Kategori Pemula Kawasan Minapolitan Budidaya Tahun 2011. Table 2. Identification SWOT in Beginner Category Minapolitan Cultivation Area, 2011.

\begin{tabular}{|c|c|}
\hline \multicolumn{2}{|c|}{ Faktor Internal/ Internal Factor } \\
\hline Kekuatan / Strength & Kelemahan /Weakness \\
\hline $\begin{array}{l}\text { Potensi lahan sangat mendukung keg- } \\
\text { iatan budidaya perikanan/ Potential of } \\
\text { land is highly supportive of aquaculture }\end{array}$ & $\begin{array}{l}\text { Kurang berfungsinya sarana\&prasarana pen- } \\
\text { dukung budidaya (pakan, benih, transportasi, } \\
\text { irigasi)/ Lack of a functioning aquaculture facili- } \\
\text { ties and supporting infrastructure (feed, seed, } \\
\text { transport, irrigation) }\end{array}$ \\
\hline $\begin{array}{l}\text { - Berfungsinya kelompok pembudidaya/- } \\
\text { Functioning of the fish farmers }\end{array}$ & $\begin{array}{l}\text { Kurangnya Kecukupan dan Kualitas air untuk } \\
\text { budidaya/ Lack of adequacy and quality of water } \\
\text { for aquaculture }\end{array}$ \\
\hline \multirow[t]{7}{*}{$\begin{array}{l}\text { Sebagian besar masyarakat setempat } \\
\text { melakukan usaha budidaya/ Most of the } \\
\text { local people do business cultivation }\end{array}$} & $\begin{array}{l}\text { Kurang berfungsinya kelembagaan pendukung } \\
\text { usaha budidaya/ Lack of a functioning institu- } \\
\text { tional business support aquaculture. }\end{array}$ \\
\hline & $\begin{array}{l}\text { - Kurang berperannya kelembagaan penyuluhan/ } \\
\text { Lack of institutional role of counseling }\end{array}$ \\
\hline & $\begin{array}{l}\text { Rendahnya pengetahuan tentang teknologi } \\
\text { budidaya perikanan/Low of knowledge about } \\
\text { aquaculture technology }\end{array}$ \\
\hline & - Lemahnya daya saing/ weak competitiveness \\
\hline & $\begin{array}{l}\text { - Rendahnya akses terhadap permodalan usaha/ } \\
\text { Poor of access to venture capital }\end{array}$ \\
\hline & $\begin{array}{l}\text { - Belum ada Sertifikasi benih/There is no seed } \\
\text { certification }\end{array}$ \\
\hline & - Harga Pakan Tinggi/ High feed rates \\
\hline
\end{tabular}

Faktor Eksternal/ External Factor

Peluang (Oppotunity)

- Komitmen pemerintah daerah dalam pengembangan Kawasan Minapolitan/ The commitment of local governments in the development area Minapolitan

- Sudah ada tata ruang kabupaten/kota/ There is already a spatial district / city

- Jangkauan pemasaran sudah mencapai di luar Kabupaten/ The marketing reach has reached beyond the District
Ancaman (Threat)

- Belum ada masterplan minapolitan/ There is no masterplan of minapolitan

- $\quad$ Tidak ada pasokan listrik untuk budidaya/ There is no electricity supply for the aquaculture.

- Terbatasnya jaringan komunikasi/Limited of communication networks

- Rendahnya harga ikan di pasaran rendah/ The low price of fish in the market 
Tabel 3. Identifikasi SWOT Pada Kategori Maju Kawasan Minapolitan Budidaya Tahun 2011. Table 3. Identification of SWOT in Advance Category Minapolitan Cultivation Area, 2011.

Faktor Internal/ Internal Factor

Kekuatan / Strength

- Memiliki sumberdaya perikanan yang sangat potensial/Has the potential of fisheries resources

- Sebagian besar masyarakat setempat melakukan usaha budidaya/_Most of the local people do business cultivation

- Tersedianya Balai Benih Ikan dan Unit Pembenihan Rakyat/ Availability of Central Seed Hatchery Fish and People's Unit

- Tersedianya sarana input produksi untuk budidaya/ Availability of Means of Production Inputs for cultivation

- Pasokan listrik, Bahan Bakar Minyak dan saluran komunikasi sudah memadai/ The supply of electricity, fuel oil and adequate communication channels

- Kondisi Infrastruktur Jalan produksi baik dan memadai/ The road conditions for the production of good and sufficient

- Tersedianya saluran irigasi/ Availability of irrigation

- Sudah ada tata ruang untuk pengelolaan perikanan budidaya/ Existing spatial structure for the management of aquaculture

- Berkembangnya kelembagaan kelompok pembudidaya/ Institutional development of fish farmers groups
Kelemahan /Weakness

Masih kurangnya tingkat pengetahuan pembudidaya tentang teknologi budidaya ikan/ The lack of knowledge level of fish farmers on cultivation technology

- Kurangnya akses terhadap permodalan usaha/ Lack of access to venture capital

- Belum ada Sertifikasi benih/ There is no seed certification

- Lemahnya daya saing/ Lack of competitiveness

\section{Faktor Eksternal/ External Factor}

\section{Peluang (Oppotunity)}

- Adanya Komitmen Pemerintah daerah dalam pengembangan kawasan minapolitan/ The commitment of local governments in the development of the area minapolitan

- Tingkat Konsumsi ikan yang semakin tinggi/ The higher the consumption of fish

\section{Ancaman (Threat)}

Penurunan kualitas air/ Decline in water quality

- Rendahnya harga ikan di pasaran / The low price of fish in the market 
Tabel 4. Identifikasi SWOT Pada Kategori Mandiri Minapolitan Budidaya Tahun 2011. Table 4. Identification SWOT in Independent Category Minapolitan Cultivation Area, 2011.

\section{Faktor Internal/ Internal Factor}

Kekuatan / Strength

- Memiliki sumberdaya perikanan yang sangat potensial/ Has the potential of fisheries resources

- Sebagian besar masyarakat setempat melakukan usaha Budidaya/ Most of the local people do business Cultivation

- Tersedianya BBI dan UPR/ Availability of Central Seed Hatchery Fish and People's Unit

- Tersedianya sarana input produksi untuk budidaya/ Availability of Means of Production Inputs for cultivation

- Pasokan listrik, Bahan Bakan Minyak dan saluran komunikasi sudah memadai/ The supply of electricity, fuel oil and adequate communication channels

- Kondisi Infrastruktur Jalan Produksi baik dan memadai/ The road conditions for the production of good and sufficient

- Tersedianya saluran irigasi/ Availability of irrigation

- Sudah ada tata ruang untuk pengelolaan perikanan budidaya/ Existing spatial structure for the management of aquaculture

- Berkembangnya kelembagaan kelompok pembudidaya/ Institutional development of fish farmers groups
Kelemahan /Weakness

Belum ada penetapan harga dasar input pakan/ There has been no determination of the basic price of feed input

- Belum ada Sertifikasi benih/ There is no seed certification

- Lemahnya daya saing/ Lack of competitiveness

\section{Faktor Eksternal/ External Factor}

\section{Peluang (Oppotunity)}

- Komitmen Pemerintah daerah dalam pengembangan kawasan minapolitan/ Commitment of local government in the development of the minapolitan

- Sudah ada RT/RW/ Already there RTRW/

- Availability the regional spatial planing

- Tingkat Konsumsi ikan yang semakin tinggi/ Fish consumption getting higher
Ancaman (Threat)

- Penurunan kualitas air / Decrease in water quality

Masuknya ikan impor/ The entry of imported Fish

Rendahnya harga ikan di pasaran/ The low price of fish in the market

Sumber: Data diolah, Tahun 2011

Source: Data processed, Year 2011 
Kategori Mandiri, unsur-unsur yang menjadi kekuatan, kelemahan, peluang dan ancaman untuk kawasan minapolitan sebagai berikut:

Kekuatan, potensi sumber daya perikanan yang sangat potensial, Sebagian besar masyarakat setempat melakukan usaha budidaya, tersedianya Balai Benih Ikan (BBI) dan Usaha Pembenihan Rakyat (UPR), tersedianya sarana input produksi untuk budidaya, pasokan listrik, bahan bakar minyak dan saluran komunikasi sudah memadai, kondisi infrastruktur jalan produksi baik dan memadai, berfungsinya saluran irigasi, sudah ada tata ruang untuk pengelolaan perikanan budidaya, berkembangnya kelembagaan kelompok pembudidaya.

Kelemahan, belum ada penetapan harga dasar input pakan, belum ada sertifikasi benih, dan lemahnya daya saing.

Peluang, komitmen pemerintah daerah dalam pengembangan kawasan minapolitan, sudah ada RTRW, tingkat konsumsi ikan yang semakin tinggi.

Ancaman, masuknya ikan impor dan harga ikan pada saat melimpah menjadi turun.

Hasil identifikasi pada kategori mandiri menggambarkan bahwa kekuatan dan peluang yang dimiliki sangat besar dan kelemahan dan ancaman yang dimiliki sudah minimal. Beberapa kelemahan yang dimiliki kawasan minapolitan berbasis perikanan budidaya untuk kategori mandiri antara lain belum adanya penetapan harga dasar input pakan, belum adanya sertifikasi benih dan lemahnya daya saing produk perikanan dengan produk luar. Sementara yang menjadi ancaman dalam pengembangan kawasan minapolitan antara lain penurunan kualitas air akibat jenuhnya kondisi lingkungan, masuknya ikan impor, dan harga ikan tidak menutupi biaya produksi.

\section{STRATEGI DAN IMPLIKASI KEBIJAKAN PENGEMBANGAN}

Terkait dengan hal tersebut diatas, rumusan strategi kebijakan pengembangan kawasan minapolitan memperhitungkan unsur-unsur kekuatan, kelemahan, kekuatan dan ancaman pada masing-masing sisi atau aspek. Berdasakan hasil perhitungan analisis SWOT untuk kategori pemula, maju dan mandiri strategi kebijakan yang di sarankan untuk pengembangan kawasan minapolitan adalah sebagai berikut:

Stategi Pengembangan Minapolitan Kategori Pemula

1. Memperkuat komitmen pemerintah daerah dalam hal dukungan anggaran untuk perbaikan sarana dan prasarana budidaya

2. Meningkatkan pemanfaatan potensi lahan budidaya dengan komoditas unggulan yang bernilai ekonomis tinggi

3. Perbaikan fasilitas infrastruktur dan fungsi sarana dan prasarana produksi budidaya perikanan melalui perbaikan saluran irigasi dan $\mathrm{BBI}$

4. Meningkatkan peran dan fungsi penyuluh perikanan

5. Mengintroduksikan paket tekonolgi melalui diseminasi inovasi dan adopsi teknologi kepada masyarakat

Stategi Pengembangan Minapolitan Kategori Maju

1. Meningkatkan kemampuan dan keterampilan masyarakat dalam usaha budidaya melalui peningkatan penguasaan tekonologi budidaya ikan

2. Perlu adanya regulasi kebijakan dan langkah nyata untuk mengatasi tingginya harga input terutama pakan

3. Perlu melakukan pembinaan dan pendampingan kepada masyarakat terutama untuk diversifiksi poduk menjadi produk olahan 
Stategi Pengembangan Minapolitan Kategori Mandiri

1. Memfasilitasi masyarakat untuk mengakses permodalan ke perbankan

2. Meningkatkan pengetahuan dan keterampilan serta pengembagan inovasi dan adopsi teknologi kepada masayarakat

3. Perlu melakukan pembinaan dan pendampingan kepada masyarakat terutama untuk diversifiksi poduk menjadi produk olahan

Berdasarkan strategi pada masingmasing kategori kesiapan pengembangan kawasan minapolitan perikanan budidaya, implikasi kebijakan yang disarankan antara lain:

Implikasi Kesiapan Pengembangan Minapolitan Katogori Pemula:

1. Pemerintah daerah komitmen terhadap pengembangan kawasan minapolitan melalui alokasi anggaran

2. Pemerintah daerah melalui dinas PU melakukan perbaikan saluran irigasi

3. Pemerintah daerah melalui Dinas KP meningkatkan peran $\mathrm{BBI}$ untuk mengasilkan induk dan benih yang berkualitas dan memiliki sertifikasi

4. Pemerintah pusat dan daerah mengintrodukksikan paket teknologi budiaya ikan, pengolahan ikan untuk meningkatkan kemampuan dan ketrampilan masyarakat sehingga produk yang dihasilkan dapat berdaya saing dengan produk impor

5. Pemerintah Pusat dan pemerintah daerah melalui Badan Pengembangan Sumberdaya Daya Manusia (BPSDM) dan Badan Penyuluh Pertanian, Perikanan, Peternakan dan Kehutanan (BP3K), meningkatkan SDM penyuluh perikanan baik secara kuantitas dan kualitas sehingga dapat memberikan informasi tentang pengetahuan dan teknologi kepada masyarakat dalam melakuakan usaha budidaya perikanan.
Implikasi Kesiapan Pengembangan Minapolitan Katogori Maju:

1. Pemerintah daerah melalui dinas Kelautan dan Perikanan melakukan pembinaan dan pendampingan kepada masyarakat sehingga dapat meningkatkan pengetahuan dan ketrampilan masyarakat dalam penguasaan teknologi

2. Pemerintah Pusat menetapkan regulasi terkait dengan penetapan harga dasar input pakan

3. Pemerintah daerah dan pusat melakukan pembinaan dan pendampingan kepada masyarakat terutama untuk diversifiksi poduk menjadi produk olahan sehingga memberikan nilai tambah terhadap pendapatan masyarakat

Implikasi Kesiapan Pengembangan Minapolitan Katogori Mandiri:

- Pemerintah daerah dan pusat lebih mensosialisasikan skim perkreditan untuk rakyat KUR melalui sosialisasi kepada masyarakat

- Pemerintah daerah dan pusat melakukan pembinaan dan pendampingan kepada masyarakat terutama untuk diversifiksi poduk menjadi produk olahan sehingga memberikan nilai tambah terhadap pendapatan masyarakat

\section{PENUTUP}

Pengembangan kawasan minapolitan merupakan stimulan dalam pertumbuhan ekonomi masyarakat pedesaan. Dalam penetapan prioritas pengembangan kawasan minapolitan perikanan budidaya perlu strategi berdasarkan tingkat kesiapannya. Skala prioritas dapat mengacu pada indeks kesiapan yaitu pemula, maju dan mandiri. Masing-masing kategori mempunyai strategi untuk pengembangan kawasan minapolitan berbasis perikanan budidaya berdasarkan identifikasi faktor internal (kekuatan dan kelemahan) dan faktor ekternal (peluang 
dan ancaman) kondisi eksisting pada kawasan minapolitan perikanan budidaya yang meliputi aspek-aspek kelembagaan, sumberdaya dan tata ruang, sistem minabisnis. kebijakan dan governance serta infrastruktur. Hal ini dilihat dari keterkaitan antara pelaku usaha dalam sistem minabisnis yang menciptakan beberapa sub sistem yakni sebagai sub sektor kegiatan hulu (pembudidaya, penyedia sarana input produksi dan saprokan, koperasi)dan kegiatan hilir berupa jaringan pemasaran dan diversifikasi produk olahan ikan. Hal ini harus didukung oleh aspek kelembagaan, sumberdaya dan tata ruang, aspek infrastruktur.

\section{DAFTAR PUSTAKA}

Anonim.2010. Model Pengembangan Kawasan Minapolitan Berbasis Budidaya. Laporan Hasil Penelitian. Balai Besar Riset Sosial Ekonomi Kelautan dan Perikanan. Badan Penelitian dan Pengembangan Kelautan dan Perikanan. Kementerian Kelautan dan Perikanan. Jakarta.

. 2011. Penataan Model Minapolitan Berbasis Budidaya. Laporan Hasil Penelitian. Balai Besar Riset Sosial Ekonomi Kelautan dan Perikanan. Badan Penelitian dan Pengembangan Kelautan dan Perikanan. Kementerian Kelautan dan Perikanan. Jakarta.
.2011. Keputusan Menteri Kelautan dan Perikanan No. 18/MEN/2011 Tentang Pedoman Umum Minapolitan. Kementerian Kelautan dan Perikanan. Jakarta.

Hasan, M. 2000. Teknik Sampling, (http://www. unpar.ac.id/home, diakses tanggal 18 Juni 2012).

Maman, Kh.U 2002. Menggabungkan Metode Penelitian Kuantitatif dan Kualitatif. IPB Press. Bogor.

Rangkuti, F. 2005. Analisis SWOT, Teknik Membedah Kasus Bisnis : Reorientasi Konsep Perencanaan Strategis untuk Menghadapi Abad 21. PT. Gramedia Pustaka Utama. Jakarta

Sunoto. 2010. Arah Kebijakan Pengembangan Konsep Minapolitan di Indonesia.[pdf]. (http://buletin.penataanruang.net/upload/ data_artikel/edis2\%20pdf2c, diakses pada tanggal 6 Mei 2012.

Vredenbreght, J. 1987. Metode dan Teknik Penelitian Masyarakat. Gramedia. Jakarta. 